\title{
Nuclear Factor $\kappa$ B Signaling Regulates Neuronal Morphology and Cocaine Reward
}

\author{
Scott J. Russo, ${ }^{1}$ Matthew B. Wilkinson, ${ }^{1 \star}$ Michelle S. Mazei-Robison, ${ }^{1 \star}$ David M. Dietz, ${ }^{1}$ Ian Maze, ${ }^{1}$ Vaishnav Krishnan, ${ }^{2}$ \\ William Renthal, ${ }^{2}$ Ami Graham, ${ }^{2}$ Shari G. Birnbaum, ${ }^{2}$ Thomas A. Green, ${ }^{2}$ Bruce Robison, ${ }^{2}$ Alan Lesselyong, ${ }^{2}$ \\ Linda I. Perrotti, ${ }^{2}$ Carlos A. Bolaños, ${ }^{2}$ Arvind Kumar, ${ }^{2}$ Michael S. Clark, ${ }^{3}$ John F. Neumaier, ${ }^{3}$ Rachael L. Neve, ${ }^{4}$ \\ Asha L. Bhakar, ${ }^{5}$ Philip A. Barker, ${ }^{5}$ and Eric J. Nestler ${ }^{1}$ \\ ${ }^{1}$ Fishberg Department of Neuroscience, Mount Sinai School of Medicine, New York, New York 10029, ${ }^{2}$ Department of Psychiatry, University of Texas \\ Southwestern Medical Center, Dallas, Texas 75390, ${ }^{3}$ Harborview Medical Center, University of Washington, Seattle, Washington 98104, ${ }^{4}$ Department of \\ Brain and Cognitive Sciences, Massachusetts Institute of Technology, Cambridge, Massachusetts 02139, and ${ }^{5}$ Montreal Neurological Institute, McGill \\ University, Montreal, Quebec, Canada H3A 2B4
}

Although chronic cocaine-induced changes in dendritic spines on nucleus accumbens (NAc) neurons have been correlated with behavioral sensitization, the molecular pathways governing these structural changes, and their resulting behavioral effects, are poorly understood. The transcription factor, nuclear factor $\kappa \mathrm{B}(\mathrm{NF} \kappa \mathrm{B})$, is rapidly activated by diverse stimuli and regulates expression of many genes known to maintain cell structure. Therefore, we evaluated the role of $\mathrm{NF} \kappa \mathrm{B}$ in regulating cocaine-induced dendritic spine changes on medium spiny neurons of the NAc and the rewarding effects of cocaine. We show that chronic cocaine induces NF $\kappa \mathrm{B}$-dependent transcription in the NAc of NF $\kappa$ B-Lac transgenic mice. This induction of NF $\kappa \mathrm{B}$ activity is accompanied by increased expression of several $\mathrm{NF} \kappa \mathrm{B}$ genes, the promoters of which show chromatin modifications after chronic cocaine exposure consistent with their transcriptional activation. To study the functional significance of this induction, we used viral-mediated gene transfer to express either a constitutively active or dominant-negative mutant of Inhibitor of $\kappa$ B kinase (IKKca or IKKdn), which normally activates NF $\kappa$ B signaling, in the NAc. We found that activation of NF $\kappa$ B by IKKca increases the number of dendritic spines on NAc neurons, whereas inhibition of NF $\kappa$ B by IKKdn decreases basal dendritic spine number and blocks the increase in dendritic spines after chronic cocaine. Moreover, inhibition of $\mathrm{NF} \kappa \mathrm{B}$ blocks the rewarding effects of cocaine and the ability of previous cocaine exposure to increase an animal's preference for cocaine. Together, these studies establish a direct role for $\mathrm{NF} \kappa \mathrm{B}$ pathways in the NAc to regulate structural and behavioral plasticity to cocaine.

\section{Introduction}

Drug addiction involves persistent alterations in the structure and function of the brain's reward circuitry, leading to motivation to take the drug (Robinson and Kolb, 2004; Hyman et al., 2006). Previous exposure to cocaine increases preference for the drug and escalates drug self-administration (Shippenberg and Heidbreder, 1995; Ahmed and Koob, 1998; Ahmed et al., 2003; Ferrario et al., 2005; Renthal et al., 2007). Drug regimens that increase the frequency of motivated behaviors [e.g., selfadminstration and conditioned place preference $(\mathrm{CPP})]$ also cause long-lasting structural changes within the nucleus accumbens (NAc) (ventral striatum), a key brain reward region. These structural changes, which include increased dendritic spine density of NAc medium spiny neurons (MSNs), correlate with sensitized behavioral responses to cocaine and other stimulant drugs

\footnotetext{
Received Dec. 29, 2008; revised Feb. 5, 2009; accepted Feb. 5, 2009.

This work was supported by grants from the National Institute on Drug Abuse and the National Institute of Mental Health.

${ }^{*}$ M.B.W. and M.S.M.-R. contributed equally to this work.

Correspondence should be addressed to Dr. Eric J. Nestler, Fishberg Department of Neuroscience, Mount Sinai School of Medicine, One Gustave L. Levy Place, Box 1065, New York, NY 10029-6574. E-mail: eric.nestler@mssm.edu. DOI:10.1523/JNEUROSCI.6173-08.2009

Copyright $\odot 2009$ Society for Neuroscience $\quad 0270-6474 / 09 / 293529-09 \$ 15.00 / 0$
}

of abuse (Robinson and Kolb, 1997, 2004; Jedynak et al., 2007). Also, electrophysiological evidence has associated the induction of behavioral sensitization with long-term potentiation (LTP) (Yao et al., 2004) or long-term depression (LTD) at excitatory glutamatergic synapses in the NAc (Ungless et al., 2001; Thomas and Malenka, 2003). Further evidence points to a slow-onset redistribution of AMPA-type glutamate receptors to the surface of NAc neurons as a critical neuroadaptation associated with sensitization (Boudreau and Wolf, 2005). Although a few reports have implicated specific molecular targets in drug-induced regulation of NAc neuron spine density (see Discussion), the detailed intracellular signaling pathways regulated by cocaine to promote structural changes in neuronal morphology, and the behavioral consequences of these changes, remain poorly defined.

Nuclear factor $\kappa \mathrm{B}(\mathrm{NF} \kappa \mathrm{B})$, a transcription factor best studied for its involvement in inflammation and immune responses (Chen and Greene, 2004; Lin and Karin, 2007), has more recently been shown to regulate synaptic plasticity and memory in the adult brain (O'Neill and Kaltschmidt, 1997; Meffert et al., 2003; Mattson, 2005; Meffert and Baltimore, 2005; Mattson and Meffert, 2006). A role for $\mathrm{NF} \kappa \mathrm{B}$ in the neural plasticity associated with drug addiction is not known; however, $\mathrm{NF} \kappa \mathrm{B}$ has been implicated in the neurotoxic effects of amphetamine derivatives in the striatum (Asanuma and Cadet, 1998), and we have shown 
previously that levels of certain $\mathrm{NF} \kappa \mathrm{B}$ subunits are regulated in the NAc by chronic cocaine (Ang et al., 2001), although the net effect of cocaine on NF $\kappa \mathrm{B}$ functional activity remains unknown.

To more clearly understand the regulation of $\mathrm{NF} \kappa \mathrm{B}$ systems by cocaine, we used a multilevel approach to characterize the effect of cocaine on the chromatin state of several $\mathrm{NF} \kappa \mathrm{B}$ genes, on levels of expression of their protein products, and on $\mathrm{NF} \kappa \mathrm{B}$ functional activity in an $\mathrm{NF} \kappa \mathrm{B}-\mathrm{LacZ}$ reporter mouse. Cocaine regulation of the $\mathrm{NF} \kappa \mathrm{B}$ system is of interest based on its involvement in nerve growth factor (NGF)-induced differentiation of pheochromocytoma (PC12) cells (Foehr et al., 2000) and brain-derived neurotrophic factor (BDNF)-induced differentiation of cultured cortical neurons (Gutierrez et al., 2005). Given the many reports implicating growth factor signaling in addiction-related structural plasticity (Russo et al., 2009), we hypothesized that NF $\kappa \mathrm{B}$ may exert a similar effect on the structure of adult NAc neurons during a course of chronic cocaine exposure and thereby contributes to drug-induced behavioral plasticity.

\section{Materials and Methods}

Animals. Male C57BL/6 mice (The Jackson Laboratory) or NF $\kappa$ B-LacZ reporter mice (Bhakar et al., 2002), weighing 25-30 g, were used for these studies. All animals were habituated to the animal facility for at least 1 week before experimental manipulation and maintained at $23-25^{\circ} \mathrm{C}$ on a $12 \mathrm{~h}$ light/dark cycle in which lights were on between 7:00 A.M. and 7:00 P.M. All animals were provided with food and water ad libitum. Experiments were conducted in accordance with guidelines of the Society for Neuroscience and Mount Sinai's institutional animal care and use committee.

Cocaine treatment. Animals were administered daily injections of cocaine $(20 \mathrm{mg} / \mathrm{kg}$, i.p.) or saline for $5 \mathrm{~d}$ and killed either $4-6$ or $24 \mathrm{~h}$ after their final injection. For neuronal morphology experiments (see Fig. 5), animals were injected with a binge cocaine regimen $(5 \times 20 \mathrm{mg} / \mathrm{kg})$ over $3 \mathrm{~d}$ and killed $4-6 \mathrm{~h}$ after their last injection to ensure that herpes simplex virus (HSV)-mediated transgene expression remained high throughout the course of cocaine treatment. It is important to note that all acute cocaine injections were preceded by $4 \mathrm{~d}$ of saline injections to control for injection stress.

Chromatin immunoprecipitation assay. Chromatin immunoprecipitation (ChIP) was performed following previously described methods (Kumar et al., 2005). First, animals were treated with cocaine $(20 \mathrm{mg} / \mathrm{kg})$ or saline for $5 \mathrm{~d}$. Four hours after the last injection, animals were killed, and their brains were removed to cold PBS. The brain was sectioned, and bilateral 14 gauge NAc punches were taken. Punches were briefly fixed in $1 \%$ formaldehyde; fixation was stopped using $2 \mathrm{~m}$ glycine. For each ChIP sample, four animals (eight punches) were pooled and sonicated on ice with a Fisher Sonic Dismembrator (Model F550) once for 25 s, followed by three $15 \mathrm{~s}$ sonications. Samples were centrifuged, and supernatant was removed to a new tube. After preclearing with protein A-agarose beads, each sample was immunoprecipitated with anti-rabbit antibodies directed against acetylated histone $\mathrm{H} 3(\mathrm{AcH} 3$; 06-599; Millipore), trimethylated lysine 4 of histone $\mathrm{H} 3(3 \mathrm{mK} 4 \mathrm{H} 3$; ab-8580; AbCam) or trimethylated lysine 9 of histone $\mathrm{H} 3(3 \mathrm{mK} 9 \mathrm{H} 3$; ab-8898; AbCam). One hundred microliters of chromatin were removed from each sample to use as input (i.e., nonimmunoprecipitated control). Samples were immunoprecipitated overnight and then washed using low salt, high salt, $\mathrm{LiCl}$ salt, and Tris-EDTA buffers. Reverse cross-linking was performed with $5 \mathrm{M}$ $\mathrm{NaCl}, 0.5 \mathrm{~m}$ EDTA, and Tris- $\mathrm{HCl}, \mathrm{pH} 6.5$, at $65^{\circ} \mathrm{C}$, and proteins were digested with RNA-grade proteinase K (Invitrogen). DNA was purified using phenol-chloroform-isoamyl alcohol extraction and resuspended in $200 \mu \mathrm{l}$ of RNase-DNase-free water (Invitrogen).

Real-time PCR. Real-time PCR was performed for the NF $\kappa \mathrm{B}$-related genes p105/50, p65/Rel-A, Inhibitor of $\kappa \mathrm{B} \alpha(\mathrm{I} \kappa \mathrm{B} \alpha)$, Inhibitor of $\kappa \mathrm{B} \beta$ $(\mathrm{I} \kappa \mathrm{B} \beta)$, and c-rel, as well as for BDNF and glial cell line-derived neurotrophic factor (GDNF). Total RNA was isolated using Trizol (Invitrogen) and an RNAeasy Micro Kit (Qiagen), mRNA was reverse transcribed using iScript (Bio-Rad), and primers were designed to amplify regions of
Table 1. ChIP primer sequences

\begin{tabular}{lll}
\hline Gene & Forward & Reverse \\
\hline p50/105 & ATTCCATCCACAGCGATGAT & CATCTGCTTGTTCCCTCCTC \\
p65/Rel-A & GGCAATTTTTGCTCCCTACA & AGAGTCCCTGAGAGCCATGA \\
$\mid \kappa B \alpha$ & TAGCCAGCGTTCCACTCTT & CAGACCTGCTAGGCTGTTCC \\
$\mid \kappa B \beta$ & CAACCTTAGCAACCGGGATA & ACCTGAAGGGAGTGGGATTC \\
$c-$ Rel & GGTATCTCGGCCAATCTCTG & CGCAGCCTTATTTTCCCTCT \\
\hline
\end{tabular}

Primer sequences used to study chromatin modifications at $\mathrm{NF} \kappa \mathrm{B}$ gene promoters.

\section{Table 2. mRNA primer sequences}

\begin{tabular}{lll}
\hline Gene & Forward & Reverse \\
\hline p105/p50 & GCCTGCAAAGGTTATCGTTC & GTCCTTGGGTCCTGCTGTTA \\
p65/Rel-A & TGTGGAGATCATCGAACAGC & GGGGTGTGTTTGGTGGTAT \\
$\mid \kappa B \alpha$ & TCGCTCTTGTTGAATGTGG & TGGAGATTTTCCAGGGTCAG \\
$\mid \kappa B \beta$ & TCAGAGCCAGGACTGTACCC & CTCTTCGTTCTCTGGGTTGG \\
BDNF & GCGGCAGATAAAAAGACTGC & TCAGTTGGCCTTGGATACC \\
GDNF & TGGGCTATGAAACCAAGGAG & CAACATGCCTGGCCTACTTT \\
\hline
\end{tabular}

Primer sequences used to study mRNA expression of $N F \kappa B$ subunits and of BDNF and GDNF.

$\sim 150$ bp located within the gene (sequences shown in Table 2). For ChIP samples, primers were designed to amplify products of $\sim 150 \mathrm{bp}$ in the regions immediately $5^{\prime}$ to the start site of the respective genes (sequences shown in Table 1). PCR was performed using an Applied Biosystems 7500 quantitative reverse transcription-PCR system with the following cycle parameters: $10 \mathrm{~min}$ at $95^{\circ} \mathrm{C} ; 40$ cycles of $95^{\circ} \mathrm{C}$ for $1 \mathrm{~min}, 60^{\circ} \mathrm{C}$ for $33 \mathrm{~s}, 72^{\circ} \mathrm{C}$ for $33 \mathrm{~s}$; and graded heating to $95^{\circ} \mathrm{C}$ to generate dissociation curves for confirmation of single PCR products. Data were analyzed by comparing cycle treshold $(\mathrm{Ct})$ values of the treatment condition (cocaine) to the control condition (saline) using the $2^{\wedge}-\Delta \Delta \mathrm{Ct}$ method (Livak and Schmittgen, 2001). Briefly, the input Ct values for each sample were subtracted from the immunoprecipitated $\mathrm{Ct}$ values $[\Delta \mathrm{Ct}]$. These values were averaged for all of the saline samples, and this value [average $\Delta \mathrm{Ct}$ ] was subtracted from the $\Delta \mathrm{Ct}$ generated for each sample above. This gives the $\Delta \Delta \mathrm{Ct}$ value for each sample. Two was raised to the negative power of each $\Delta \Delta \mathrm{Ct}$ giving the fold change induced by cocaine in NF $\kappa \mathrm{B}$-related genes. Several genes not regulated by cocaine were studied as controls; these included $\beta$-tubulin and histone H4, among others. Samples were normalized such that saline samples showed no fold change (i.e., a fold change of 1).

Immunohistochemistry. Mice were sequentially perfused with cold $1 \times$ PBS, followed by $4 \%$ paraformaldehyde in $1 \times \mathrm{PBS}$ at a $\mathrm{pH}$ of 7.4 , and the intact brains were removed, cryoprotected in PBS containing 30\% sucrose, and later sectioned and processed for immunohistochemistry according to previously published protocols (Russo et al., 2007). Briefly, sections were incubated in blocking buffer (containing donkey serum) and then with either anti-rabbit green fluorescent protein (GFP) (Abcam), or anti-goat $\beta$-galactosidase ( $\beta$-gal) (Biogenesis) primary antibodies. Sections were then incubated either with $\mathrm{Cy} 2$ and $\mathrm{Cy} 3$ secondary fluorophores or a biotinylated rabbit anti-goat secondary antibody (DakoCytomation) and avidin-biotin complexes, followed by peroxidase labeling using a DAB substrate kit (Vector Laboratories). Neurons were analyzed under bright-field microscopy or with a Zeiss 560LSM confocal microscope under $63 \times$ or $100 \times$.

Immunoblotting. Immunoblotting from NAc lysate was performed as described previously (Russo et al., 2007). After chronic cocaine treatment, brains were removed from decapitated mice, placed on ice, and sectioned on a brain matrix at a thickness of $1 \mathrm{~mm}$, and tissue punches were taken with a 15 gauge cannula and frozen at $-80^{\circ} \mathrm{C}$ until used. Tissue punches were sonicated on ice in a modified detergent-based buffer also containing $50 \mathrm{~mm} \mathrm{NaF}$ (to inhibit protein phosphatase activity), protease inhibitor mixture I, and phosphatase inhibitor mixtures I and II from Sigma. After sonication, samples were centrifuged at $15,000 \times g$ for $15 \mathrm{~min}$, and the supernatant was collected and processed for protein concentration determination using a Lowry assay from BioRad. For Western blotting, $30 \mu \mathrm{g}$ of protein/sample were run on a Criterion 4-20\% acrylamide/bisacrylamide gradient gel from Bio-Rad, transferred to a polyvinylidene difluoride membrane, blocked with $4 \%$ 
milk, and incubated using primary antibodies against anti-mouse Inhibitor of $\kappa$ B kinase (IKK) $\beta$, anti-rabbit p65/Rel-A, p105/p50, I $\kappa$ B $\alpha, \mathrm{I} \kappa \mathrm{B} \beta$ (Santa Cruz Biotechnology), and anti-rabbit phospho-p65/Rel-A (Cell Signaling Technology).

Construction of viral vectors. Coding sequences for the $\beta$ form of either wild-type IKK (IKKwt) or a dominant-negative mutant [IKKdn; lysine 44 was substituted with methionine (Mercurio et al., 1997)] and subcloned into the bicistronic p1005 + HSV plasmid (Clark et al., 2002). For a constitutively active mutant [IKKca; serine 177 and 181 were mutated to glutamate (Mercurio and Manning, 1999) (kindly provided by Z. Chen, University of Texas Southwestern Medical Center, Dallas, TX)], we designed primers with $K p n I$ restriction sites (forward primer, CAAGGTACCARGAGCTGGTCACCTTCCC; and reverse primer, CAAGGTACCTCATGAGGCCTGCTCCA). Fragments were subcloned into the bicistronic p1005+ HSV plasmid at Kpn1.

Stereotaxic surgery. Mice were anesthetized with a mixture of ketamine $(100 \mathrm{mg} / \mathrm{kg})$ and xylazine $(10 \mathrm{mg} / \mathrm{kg})$ and positioned in a small-animal stereotaxic instrument (Kopf Instruments), and the skull surface was exposed. Thirty-three gauge syringe needles (Hamilton) were used to bilaterally infuse $0.5 \mu \mathrm{l}$ of virus into the NAc at a rate of $0.1 \mathrm{ml} / \mathrm{min}$ (Graham et al., 2007; Krishnan et al., 2007).

Behavior analysis. The place conditioning procedure was conducted as previously described (Russo et al., 2007), with the following modifications. Briefly, $3 \mathrm{~d}$ after intra-NAc infusions of HSV-IKKwt, HSV-IKKdn, or HSV-GFP, mice were placed into the conditioning chambers, which consist of three distinct environments. Mice that showed any significant preference for either of the two conditioning chambers $(<10 \%$ of all animals investigated) were excluded from the study. On subsequent days, animals were injected with saline and confined to one chamber in the morning for $30 \mathrm{~min}$ and then injected with cocaine $(2.5-10 \mathrm{mg} / \mathrm{kg}$, i.p.) and confined for $30 \mathrm{~min}$ to the alternate chamber in the afternoon for $2 \mathrm{~d}$ (two cocaine and two saline pairings). On the test day, mice were placed back into the apparatus in a drug-free state for $20 \mathrm{~min}$ and tested to determine which side they prefer. To control for unconditioned chamber bias, all experimental conditions included a group of mice that were administered saline in both chambers.

As we show in Figure 6, $A$ and $B$, sensitization to the rewarding effects of cocaine was conducted as described previously with the following modifications (Shippenberg and Heidbreder, 1995; Renthal et al., 2007). Eight-week-old mice were injected with HSV-IKKdn, HSV-IKKca, or HSV-GFP into the NAc via stereotaxic injection. The animals were given cocaine ( $20 \mathrm{mg} / \mathrm{kg}$, i.p., for $4 \mathrm{~d}$ ) at the onset of HSV expression, and after 3 additional days without treatment, animals received CPP training as described above with $5 \mathrm{mg} / \mathrm{kg}$ cocaine. As a result of the transient transgene expression seen with HSV vectors, with peak expression between days 1 and 4 subsiding to zero by days 6-7 (Barrot et al., 2002), we used this paradigm to test the role of NF $\kappa \mathrm{B}$ signaling on sensitization to cocaine during a chronic exposure to the drug. Baseline locomotor activity was measured using a photobeam system (San Diego Instruments) $3 \mathrm{~d}$ after stereotaxic delivery of HSV vectors. We confirmed that viral gene transfer of IKK mutants alone did not affect baseline locomotor activity, and thus did not cause gross behavioral deficits unrelated to cocaine reward.

NGF-induced PC12 cell differentiation. To determine whether NF $\kappa \mathrm{B}$ regulates NGF-induced PC12 cell differentiation, we plated cells at 50\% confluency (undifferentiated) in chamber slides. Twenty-four hours $h$ later, cells were infected with HSV-IKK mutants (diluted 1:3 with $\mathrm{H}_{2} \mathrm{O}$ to prevent any cell death) and, after $6-8 \mathrm{~h}$, NGF was added at a concentration of $100 \mathrm{ng} / \mathrm{ml}$ once daily for $3 \mathrm{~d}$ until HSV-GFP-infected cells began to branch. On day 3, cells were washed with $1 \times$ PBS, fixed in $1 \%$ formaldehyde, and processed for immunohistochemistry. Briefly, cells were incubated in blocking solution containing $0.25 \%$ cold-water fish gelatin and $0.04 \%$ saponin and then incubated with a primary antibody against GFP. Cells were then washed and incubated with Cy2 secondary fluorophores. To measure neurite differentiation, pictures were taken at $40 \times$, and the total number of cells (30-50 per image) undergoing neurite differentiation were assessed by counting the number of neurite protrusions from the soma. Given that these data had been previously shown, we used this technique as a proof-of-principle procedure to validate our viral constructs for in vivo work and did not further examine the qualitative differences between the groups. Data presented are from three independent samples and are expressed as the mean percentage of cells with any detectable neurite formation.

Slice pharmacology. Acute bilateral NAc punches were subjected to pharmacological manipulation as described previously (Renthal et al., 2007 ). Briefly, adult male mice ( $\sim 9$ weeks old) were killed by decapitation, and brains were removed and placed in cold, oxygenated Krebs buffer (124 mм NaCl, 4 mm KCl, 26 mм NaHCO 3,10 mm D-glucose, 1.5 $\mathrm{mM} \mathrm{CaCl}_{2}, 1.5 \mathrm{~mm} \mathrm{MgSO}_{4}$, and $1.25 \mathrm{~mm} \mathrm{KH}_{2} \mathrm{PO}_{4}, \mathrm{pH}$ 7.4). NAc punches ( $1 \mathrm{~mm}, 14$ gauge) were transferred to tubes containing $4 \mathrm{ml}$ of normal Krebs buffer and were allowed to recover at $30^{\circ} \mathrm{C}$ under continual oxygenation $\left(95 \% \mathrm{O}_{2} / 5 \% \mathrm{CO}_{2}\right)$ for $60 \mathrm{~min}$. Punches were subsequently incubated for $30 \mathrm{~min}$ with or without BDNF in a $20 \mathrm{~mm} \mathrm{~K}^{+}$depolarizing Krebs buffer (109.25 mm NaCl, $18.75 \mathrm{~mm} \mathrm{KCl,} 26 \mathrm{~mm} \mathrm{NaHCO}_{3}, 10 \mathrm{~mm}$ D-glucose, $3 \mathrm{mM} \mathrm{CaCl}_{2}$, and $1.25 \mathrm{~mm} \mathrm{KH}_{2} \mathrm{PO}_{4}$, pH 7.4). Punches were then transferred to Microfuge tubes (LabScientific), frozen on dry ice, and stored at $-80^{\circ} \mathrm{C}$ before RNA isolation.

Use of bicistronic HSV vectors to measure NAc neuron spine density. To study the role of $\mathrm{NF} \kappa \mathrm{B}$ in regulating neuronal morphology in vivo, we used methods previously described with the following modifications (Pulipparacharuvil et al., 2008). Three days after injection of HSV-GFP, HSV-IKKdn, or HSV-IKKca, when viral expression is maximal, mice were perfused, and brains were cryoprotected and sectioned on a vibratome at $100 \mu \mathrm{m}$. Sections were then immunostained using an antibody against GFP according to a previously published protocol (Russo et al., 2007) and described above. To assess the effects of NF $\kappa$ B on spine numbers, we measured the number of spines on approximately one to two neurites per neuron equaling at least $100 \mu \mathrm{m}$ of secondary dendrites from GFP-expressing MSNs in the NAc. For each group, we examined $\sim 30$ neurons in four to eight animals, after which an average value was obtained for each animal for statistical analysis. All images were captured with a confocal microscope (Zeiss) using a $100 \times$ oil-immersion objective. Images were acquired with the pinhole set at 1 arbitrary unit and a $1024 \times 1024$ frame size. The average stacks for the $x$ - and $y$-plane were $\sim 90$ and $5 \mu \mathrm{m}$ for the $z$-plane. Dendrite length was measured using NIH ImageJ software, and dendritic spine number was counted by two trained observers that were blind to the experimental condition. The average number of spines per $10 \mu \mathrm{m}$ of dendrite was calculated.

In vivo LacZ activity and cell surface area measurement. To quantify the surface area of MSNs in the NAc, rats received bilateral injections of HSV vectors, and GFP was detected by immunohistochemistry, as described above. We acquired confocal $z$-scans of MSNs, defined by spine morphology, which were reconstructed in three dimensions using Volocity software (Improvision), and the surface area and pixel intensity of these neurons were measured. For cells to be chosen for morphological analysis, consistent cytoplasmic staining patterns throughout the entire cell body for GFP were required. Any cells with overlapping cell bodies or dendritic processes that interfered with the accuracy of cell measurements were omitted. Cells that met these criteria were sampled throughout the rostral-caudal extent of the NAc. Each confocal scan captured approximately two infected neurons meeting the criteria, and within each field of cells, 10-20 uninfected LacZ-expressing cells were measured to serve as internal controls. Approximately 15 neurons from three animals were used for each virus treatment.

Statistical analysis. All data are expressed as the mean \pm SEM. Mean differences between groups were determined using a Student's $t$ test or a one-way ANOVA followed by Newman-Keuls post hoc tests when the main effect was significant at $p<0.05$. Statistical analyses were conducted using software from GraphPad Prism 4.0.

\section{Results}

\section{Cocaine-induced chromatin modifications on NF $\kappa \mathrm{B}$ genes}

Prior studies have shown that cocaine increases protein levels of two NF $\kappa$ B subunits, p105/p50 and p65/Rel-A, in the NAc (Ang et al., 2001). To determine whether such adaptations may be mediated at the transcriptional level, we used ChIP to examine two markers of gene activation, acH3 and $3 \mathrm{mK} 4 \mathrm{H} 3$, and one marker 
A $\mathrm{acH} 3$

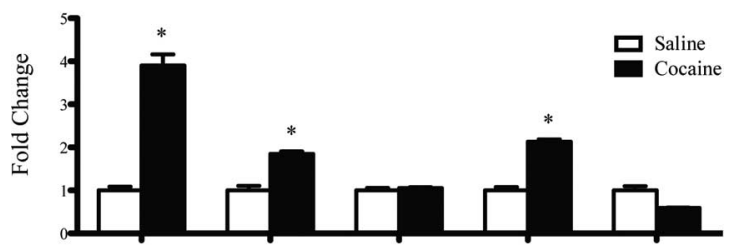

B $3 \mathrm{mK} 9 \mathrm{H} 3$

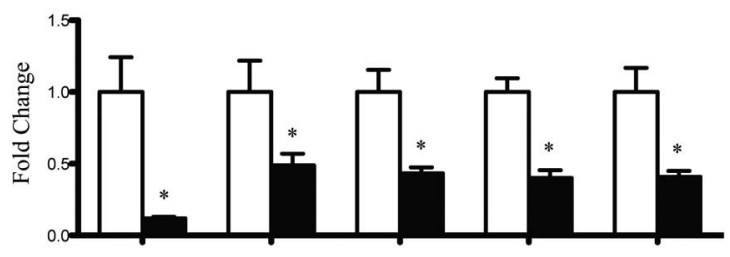

C $3 \mathrm{mK} 4 \mathrm{H} 3$

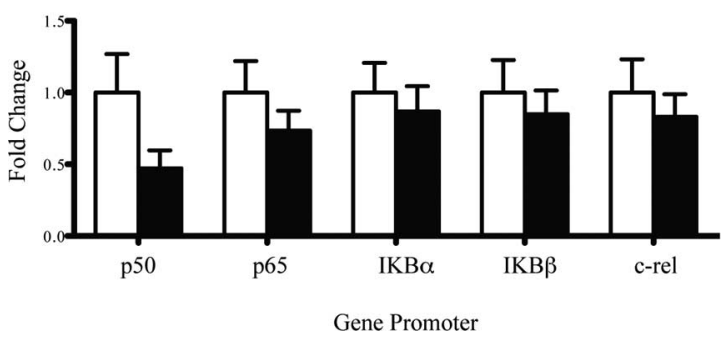

Figure 1. Cocaine regulates acetylation of histone $\mathrm{H} 3(\mathrm{acH} 3)$ and trimethylation of $\mathrm{Lys} 9$ of $\mathrm{H} 3(3 \mathrm{mK} 9 \mathrm{H} 3)$ on NF $\kappa$ B gene promoters (tissue was collected $4-6 \mathrm{~h}$ after cocaine administration). $\boldsymbol{A}$, Increased binding of acH3 at the $\mathrm{p} 105 / \mathrm{p} 50, \mathrm{p} 65 /$ Rel-A, and $\mathrm{I}_{\kappa} \mathrm{B} \beta$ promoters $\left({ }^{*} p<\right.$ 0.05 , Student's $t$ test, $n=6-8)$, and no significant changes on the $\mid \kappa B \alpha$ or c-rel promoters. $B$ A general decrease in $3 \mathrm{meK} 9 \mathrm{H} 3$ binding, a repressive mark, on all $\mathrm{NF} \kappa \mathrm{B}$ promoters examined $\left({ }^{*} p<0.05\right.$, Student's t test, $\left.n=6-8\right)$. In contrast, $C$ shows no changes in $3 \mathrm{mK} 4 \mathrm{H} 3$ binding at any of the NF $\kappa$ B promoters. All data are expressed as mean fold change \pm SEM and are normalized to total input DNA.

of gene repression, $3 \mathrm{mK} 9 \mathrm{H} 3$, at several $\mathrm{NF} \kappa \mathrm{B}$ genes. We found that chronic cocaine administration increases levels of acH3 at the p105/p50, p65/Rel-A, and $\mathrm{I} \kappa \mathrm{B} \beta$ genes (p105/p50: $t_{(12)}=$ 3.314, $p<0.01$; p65: $t_{(12)}=2.946, p<0.05 ; \mathrm{I} \kappa \mathrm{B} \beta: t_{(12)}=4.660$, $p<0.001$ ) (Fig. $1 A$ ). No changes in acH3 were observed on c-rel or $\mathrm{I} \kappa \mathrm{B} \alpha$ genes. In contrast, chronic exposure to cocaine decreased $3 \mathrm{mK} 9 \mathrm{H} 3$ binding at all of the NF $\mathrm{B}$ promoters studied ( $\mathrm{p} 105 /$ p50: $t_{(9)}=3.281, p<0.05 ; \mathrm{p} 65: t_{(10)}=2.200, p=0.05 ; \mathrm{I} \kappa \mathrm{B} \alpha: t_{(10)}$ $=3.546, p=0.05 ; \mathrm{I} \kappa \mathrm{B} \beta: t_{(10)}=5.493, p<0.05$; c-rel: $t_{(10)}=$ 3.415, $p<0.05$ ) (Fig. $1 B$ ), whereas binding of $3 \mathrm{mK} 4 \mathrm{H} 3$ was unaltered (Fig. 1C). No changes in levels of acH3, $3 \mathrm{mK} 4 \mathrm{H} 3$, or $3 \mathrm{mK} 9 \mathrm{H} 3$ were observed on several control genes studied for comparison (see Materials and Methods). Given that acH3 is a known marker of gene activation, whereas $3 \mathrm{mK} 9 \mathrm{H} 3$ is a marker of gene repression, it is interesting to note that these two modifications may be acting synergistically at NF $\kappa \mathrm{B}$ promoters to control gene expression (Kurdistani et al., 2004).

\section{Cocaine increases NF $\kappa \mathrm{B}$-dependent signaling in the NAc}

Given the relatively high expression of certain $\mathrm{NF} \kappa \mathrm{B}$ subunits in the NAc and dorsal striatum (Asanuma and Cadet, 1998; Ang et al., 2001), we first determined the relative activity patterns of $\mathrm{NF} \kappa \mathrm{B}$-dependent transcription throughout the striatum. Using a transgenic $\mathrm{NF} \kappa \mathrm{B}-\mathrm{LacZ}$ reporter mouse treated chronically with cocaine, we demonstrated high levels of $\mathrm{NF} \kappa \mathrm{B}$ transcriptional activity, as determined by $\beta$-gal expression, throughout the NAc (core and shell) and dorsal striatum (i.e., caudate-putamen) (Fig. 2A).

Although previous data showed that chronic exposure to cocaine increases total protein levels of the p105/p50 and p65/Rel-A NF $\kappa$ B subunits in the NAc (Ang et al., 2001), it has remained unclear whether these changes correspond to any net functional change in $\mathrm{NF} \kappa \mathrm{B}$-dependent transcription, because among the upregulated

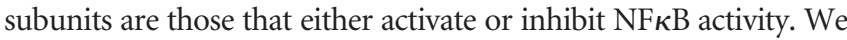
first replicated our published data showing that chronic cocaine administration increases levels of expression of the NF $\kappa \mathrm{B}$ subunits, p65/Rel-A $\left(t_{(12)}=2.170, p<0.05\right)$ and p105/50 $\left(t_{(12)}=3.171, p<\right.$ $0.05)$, in the NAc; there was also a strong trend toward increased levels of $\operatorname{I} \kappa \mathrm{B} \beta\left(t_{(11)}=1.449, p=0.08\right)$ (Fig. 3), which was not examined in our previous study. In addition, we did not observe any change in NAc levels of $\mathrm{I} \kappa \mathrm{B} \alpha(p>0.05)$, and c-rel was not detectable by Western blotting in this brain region. Importantly, the three $\mathrm{NF} \kappa \mathrm{B}$ subunits that showed evidence of induction in the NAc after chronic cocaine administration (Fig. 3) also showed evidence of transcriptional activation based on increased binding of acH3 to their gene promoters (Fig. $1 A$ ).

To determine the net effect of these adaptations in NF $\kappa$ B subunit expression on $\mathrm{NF} \kappa \mathrm{B}$-dependent transcription, we counted the number of $\beta$-gal-positive nuclei in the NAc of saline- and cocaine-treated $\mathrm{NF} \kappa \mathrm{B}-\mathrm{LacZ}$ reporter mice. As shown in Figure $2 B$, chronic cocaine increases the number of $\beta$-gal-positive nuclei in the shell subregion of the NAc $4-6 \mathrm{~h}$ after the last injection (ANOVA, $F_{(2,6)}=7.656, p<0.05$ and post hoc $p<0.05$ ). In contrast, no effect was seen in the core subregion or in the dorsal striatum (data not shown). The increase in $\beta$-gal expression is maintained for at least $24 \mathrm{~h}$ after the last injection only in animals treated chronically with cocaine (ANOVA, $F_{(2,9)}=8.513, p<$ 0.05 and post hoc $p<0.05$ ) (Fig. $2 B$ ).

\section{Validation of viral vectors}

Having demonstrated that cocaine induces $\mathrm{NF} \kappa \mathrm{B}$ activity in the NAc, we next sought to study the influence of this transcription factor on neural and behavioral effects of cocaine. To achieve this goal, we developed HSV vectors that express IKKwt, IKKca, or IKKdn. IKK functions to activate NF $\kappa \mathrm{B}$ signaling in diverse cell types. IKKca and IKKdn differ from IKKwt by single- or doublepoint mutations only (Mercurio et al., 1997; Mercurio and Manning, 1999). We used multiple approaches in vitro and in vivo to verify the appropriate transgene expression and activity from these novel HSV vectors. As shown in supplemental Figure $2 F$, all three vectors expressed IKK at similar levels in PC12 cells. Additionally, both IKKwt and IKKca expression increased levels of phospho-p65/ Rel-A, without changing its total levels, in PC12 cells (supplemental Fig. $2 F$, available at www.jneurosci.org as supplemental material), as would be expected. Viral-mediated overexpression of IKKca in the $\mathrm{NAc}$ of $\mathrm{NF} \kappa \mathrm{B}$-LacZ reporter mice showed that IKKca significantly increased $\beta$-gal expression (supplemental Fig. $2 D$, available at www.jneurosci.org as supplemental material), an effect not seen for IKKwt (ANOVA, $F_{(3,50)}=10.99, p<0.05$ and post hoc $p<0.05$ ). Therefore, all subsequent behavior and morphology experiments used the IKKca vector to activate NF $\kappa$ B. In unstimulated PC12 cells, basal levels of phospho-p65/Rel-A were undetectable, which prevented us from assessing the utility of IKKdn in decreasing NF $\kappa \mathrm{B}$ activity in vitro (supplemental Fig. $2 F$, available at www.jneurosci. org as supplemental material). However, given the high constitutive activity of $\mathrm{NF} \kappa \mathrm{B}$ in the NAc of $\mathrm{NF} \kappa \mathrm{B}-\mathrm{LacZ}$ reporter mice, we were able to test its efficacy in vivo. Indeed, we verified a $50 \%$ reduction of $\mathrm{NF} \kappa \mathrm{B}$ activity upon intra-NAc injection of HSV-IKKdn compared 

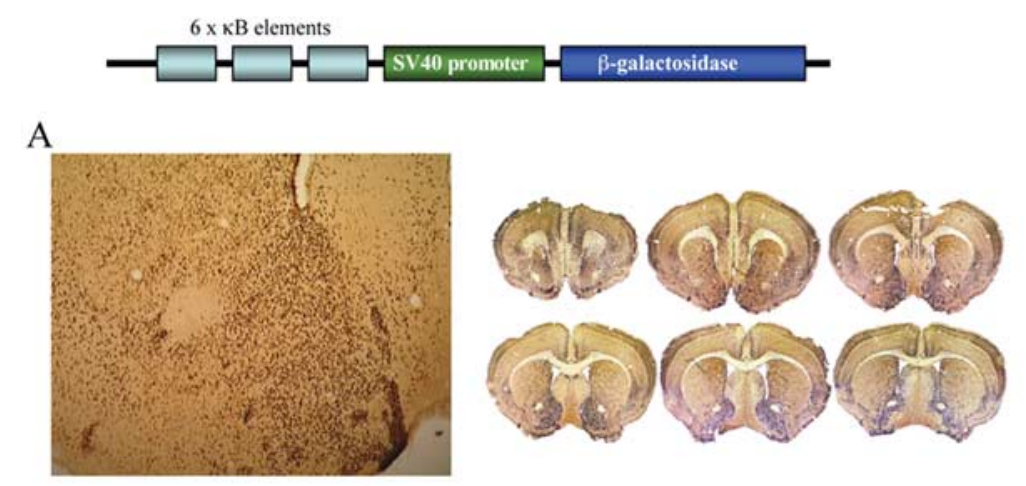

B
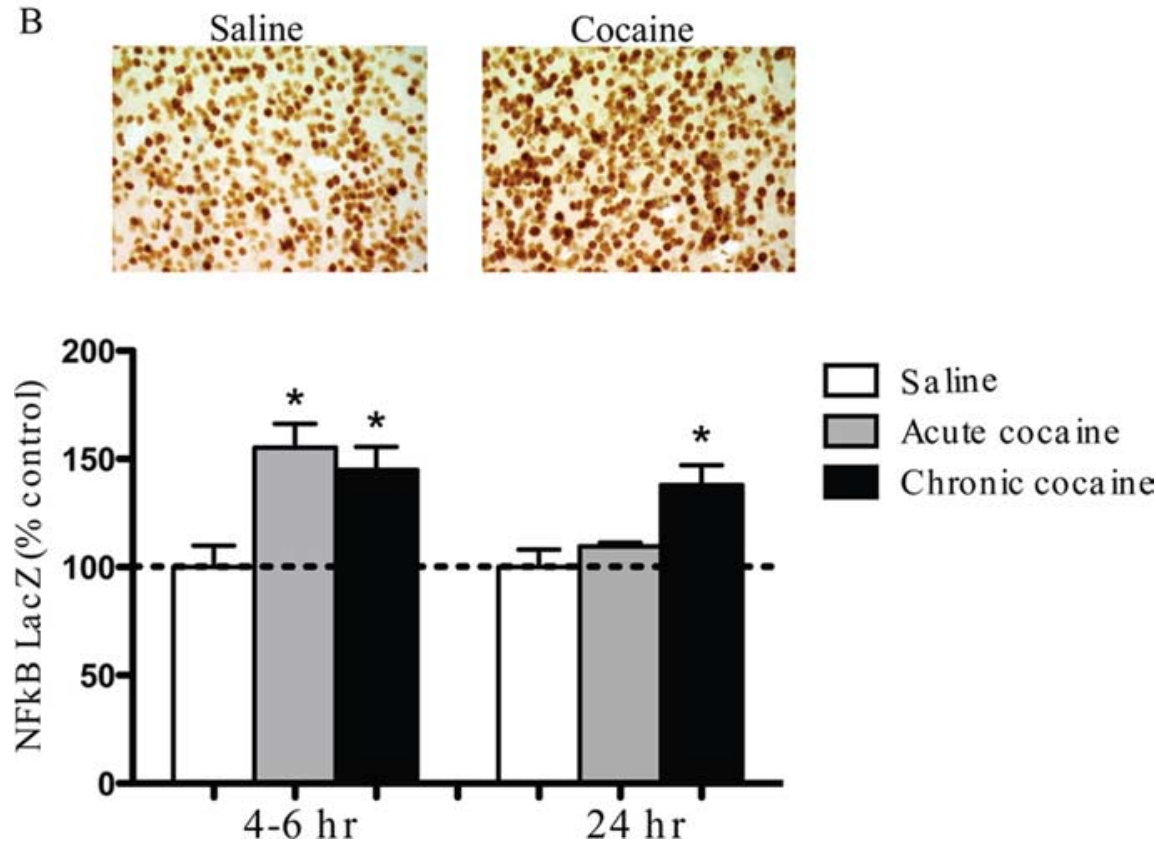

Figure 2. Cocaine regulates NF $\kappa$ B-dependent gene transcription in striatum. $A$, The NF $\kappa$ B-LacZ reporter construct as well as a $20 \times$ image of NF $\kappa B$ activity in the NAc shell and core, and $4 \times$ photomicrographs of the relative distribution of activity throughout the anterior to posterior gradient, as marked by $\beta$-gal immunohistochemistry $(\boldsymbol{B})$. NF $\kappa$ B-dependent transcription was measured in the NAc shell $4-6$ and $24 \mathrm{~h}$ after saline, acute, or chronic cocaine. Representative photomicrographs of $\beta$-gal expression after saline or chronic cocaine are shown. The bar graph shows that NF $\kappa \mathrm{B}$-dependent $\beta$-gal expression is increased in the NAc shell only by acute or chronic cocaine $\left({ }^{*} p<0.05\right.$, ANOVA, $\left.n=3-5\right)$.

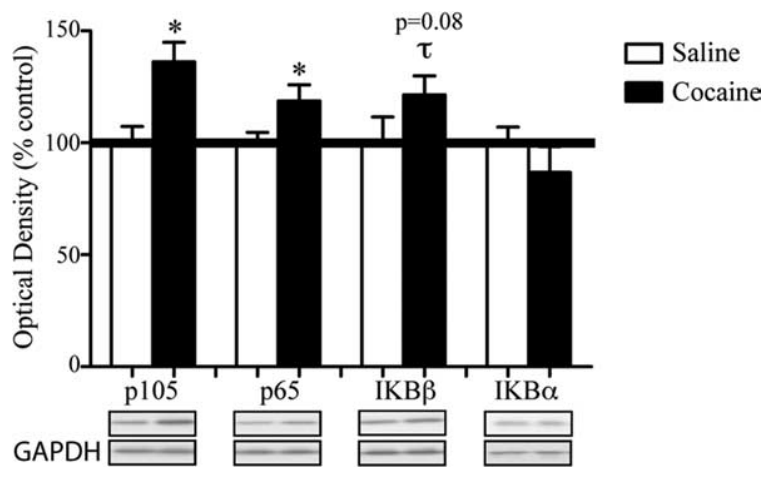

Figure 3. Chronic cocaine increases protein levels of certain $N F \kappa B$ subunits in the NAc. The figure shows via Western blotting that $4-6 \mathrm{~h}$ after chronic cocaine there are increased levels of the NF $\kappa$ B subunits p65/Rel-A ( ${ }^{*} p<0.05$, Student's $t$ test, $\left.n=7-8\right)$ and $p 105\left({ }^{*} p<0.05\right.$, Student's $t$ test, $n=7-8$ ), with a strong trend for $I_{\kappa} B \beta$ as well ( ${ }^{\top} p=0.08$, Student's $t$ test, $n=7-8)$, but not the inhibitory $I_{\kappa} B \alpha$ subunit. All data are expressed as the mean optical density percentage control \pm SEM. with HSV-GFP as a control $(p<0.05)$ (supplemental Fig. 2D, available at www. jneurosci.org as supplemental material).

\section{Molecular cross-talk between NF $\kappa$ B and BDNF}

Given the known interactions between neurotrophic factors and $\mathrm{NF} \kappa \mathrm{B}$ signaling in other cell lines, we studied possible cross-talk between these two pathways in the NAc. We first injected HSV vectors expressing mutant IKK proteins into the NAc and found that overexpression of IKKca increased levels of BDNF mRNA in this brain region (ANOVA, $F_{(2,14)}=3.149, p<0.05$ and post hoc $p<$ $0.05)$ (Fig. 4). There was a trend for IKKdn overexpression to decrease BDNF mRNA levels, although this result was not statistically significant $(p=0.08)$. In contrast, neither IKKca nor IKKdn overexpression altered levels of GDNF mRNA in the NAc $(p>0.05)$. These findings suggest that $\mathrm{BDNF}$ is a target of $\mathrm{NF} \kappa \mathrm{B}$ signaling in the NAc. Conversely, we then treated NAc slices ex vivo with purified BDNF protein and examined the mRNA levels of several NF $\kappa \mathrm{B}$ related genes. It was found that BDNF increased mRNA levels of $\mathrm{I} \kappa \mathrm{B} \alpha(140 \pm 9 \%$ of control, $\left.t_{(12)}=2.644, p<0.05\right)$, which is typically increased in response to NF $\kappa \mathrm{B}$ activation of other tissues, without affecting mRNA levels of other NF $\kappa \mathrm{B}$ subunits (data not shown).

\section{$\mathrm{NF} \kappa \mathrm{B}$ regulates dendritic spines in NAc MSNs}

The observation that alterations in $\mathrm{NF} \kappa \mathrm{B}$ activity in the NAc regulates BDNF expression raised the possibility that such alterations might influence the morphology of NAc neurons. We therefore used the HSV-IKK vectors to directly investigate the influence of $\mathrm{NF} \kappa \mathrm{B}$ signaling on dendritic spine density in the NAc. For proof of principle, we first screened the HSVIKK mutants in a cell-culture-based assay of differentiation. NGF treatment of PC12 cells, a pheochromocytoma cell line with neuron-like characteristics, leads to differentiation and neurite outgrowth. As shown in Figure 5, $D$ and $E$, we found that expression of IKKdn during NGF treatment blocked neurite formation, whereas HSV-mediated expression of IKKca greatly enhanced neurite formation (ANOVA, $F_{(2,21)}=18.21$, $p<0.05$ and post hoc $p<0.05$ ).

Given these robust effects, we investigated the effect of these vectors on basal and cocaine-induced dendritic spine density of MSNs in the NAc (ANOVA, $F_{(4,25)}=16.79, p<0.05$ and post hoc, $p<0.05)$. Under basal conditions, we found that overexpression of IKKdn decreased the density of dendritic spines, whereas overexpression of IKKca enhanced dendritc spine density on these neurons (Fig. $5 A-C$ ). Importantly, we found that expression of IKKdn blocks the ability of chronic cocaine to increase dendritic spines on NAc neurons (Fig. 5C). 


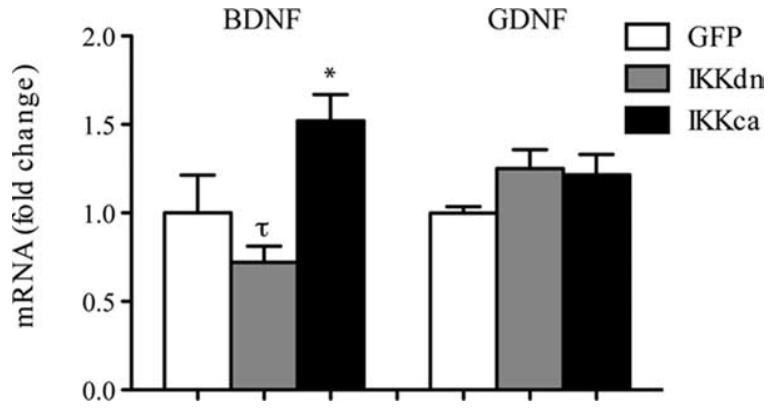

Figure 4. Molecular cross-talk between BDNF and NF $\kappa$ B signaling in the NAc. Expression of HSV-IKKca increases BDNF mRNA ( ${ }^{*} p<0.05$, ANOVA, $\left.n=5-6\right)$ and HSV-IKKdn expression produced a trend for decreased BDNF mRNA in the NAc ( $\left.{ }^{\tau} p=0.08\right)$. Neither manipulation altered GDNF mRNA levels in the NAc. Data are expressed as the mean fold change of control \pm SEM.

\section{$\mathrm{NF} \kappa \mathrm{B}$ in the NAc regulates cocaine reward}

We next determined the ability of alterations in NF $\kappa \mathrm{B}$ activity in the NAc to regulate behavioral responses to cocaine. In drug naive mice, inhibition of $\mathrm{NF} \kappa \mathrm{B}$ in the $\mathrm{NAc}$, via bilateral injection of HSV-IKKdn, significantly attenuated cocaine CPP at 5 (ANOVA, $F_{(2,35)}=7.644, p<0.05$ ) and $10 \mathrm{mg} / \mathrm{kg}$ (ANOVA, $\left.F_{(2,16)}=7.644, p<0.05\right)$ training doses of cocaine, whereas activation of $\mathrm{NF} \kappa \mathrm{B}$, via bilateral injection of HSV-IKKca, had no effect (Fig. 6A). We then used a CPP reward sensitization paradigm, in which animals are first treated with cocaine for $4 \mathrm{~d}$, allowed to rest drug free for $4 \mathrm{~d}$, and then trained for cocaine CPP. Such prior exposure to cocaine makes animals more sensitive to cocaine's rewarding effects; this is shown in Figure $6 B$ (two-way ANOVA, $\left.F_{(2,73)}=20.57, p<0.05\right)$, in which animals injected bilaterally with HSV-GFP showed enhanced CPP after prior chronic exposure to the drug $\left(t_{(29)}=2.039, p<0.05\right)$. Interestingly, inhibition of $\mathrm{NF} \kappa \mathrm{B}$ with IKKdn overexpression completely blocked the development of reward sensitization (Fig. 6B). Because transgene expression dissipates before the beginning of CPP training (5-7 d), these findings suggest that inhibition of $\mathrm{NF} \kappa \mathrm{B}$ during prior drug exposure attenuates this behavioral adaptation. Overexpression of IKKca during the prior cocaine course had no effect in this behavioral paradigm; animals sensitized similar to controls $\left(t_{(14)}=2.065, p<0.05\right)$. As a control, we found that neither IKK virus, when injected into the NAc, affected conditioning to saline $(0 \mathrm{mg} / \mathrm{kg}$ cocaine dose in Fig. $6 \mathrm{~A})$, nor did they alter general locomotor activity, which is necessary for the expression of CPP behavior (GFP, $74.65 \pm 15.56$; IKKdn, $69.40 \pm 14.47 ;$ IKKca, $74.4 \pm 15.51)$.

\section{Discussion}

It has been hypothesized previously that cocaine induction of dendritic branching and spine formation in MSNs of the NAc mediates behavioral sensitization, namely, increased behavioral responses to the drug after repeated administration (Robinson and Kolb, 1997, 2004). We have extended these findings to specifically implicate an increase in $\mathrm{NF} \kappa \mathrm{B}$ signaling during cocaine administration as a key mediator of these adaptations. The results of the present study show that cocaine upregulates $\mathrm{NF} \kappa \mathrm{B}$ signaling in the NAc and that this signaling pathway is crucial for controlling the morphology of NAc neurons as well as regulating the rewarding responses to cocaine. Specifically, we show that blockade of $\mathrm{NF} \kappa \mathrm{B}$ in this brain region decreases cocaine reward, as measured by CPP. We show further, by use of novel bicistronic $\mathrm{HSV}$ vectors to upregulate or downregulate NF $\kappa$ B activity specifically within the NAc of adult animals, that inhibition of $\mathrm{NF} \kappa \mathrm{B}$ decreases the number of dendritic spines on MSNs, whereas activation of $\mathrm{NF} \kappa \mathrm{B}$ signaling increases dendritic spine density. Future work is needed to determine how long enhanced $\mathrm{NF} \kappa \mathrm{B}$ signaling persists in the NAc after cessation of chronic cocaine administration and whether $\mathrm{NF} \kappa \mathrm{B}$ is required not only for the induction of increased dendritic spines on MSNs but also their long-term maintenance.

$\mathrm{NF} \kappa \mathrm{B}$ has received much attention in recent years as a prosurvival transcription factor that is important during inflammatory and immune responses. Numerous studies have shown that NFкB knock-out mice have increased cell death in response to an excitotoxic lesion (Yu et al., 1999; Kassed et al., 2002). A previous study demonstrated activation of $\mathrm{NF} \kappa \mathrm{B}$ activity in dorsal striatum in response to methamphetamine, a treatment that is known to induce neuronal cell death in this brain region (Asanuma and Cadet, 1998). However, no causal evidence was provided that $\mathrm{NF} \kappa \mathrm{B}$ induction per se mediates the cell death observed; in fact, it is possible that NF $\kappa \mathrm{B}$ induction represents a homeostatic response to limit drug-induced neural damage. In contrast to methamphetamine, cocaine, at least at the dosing schedules used here, does not induce cell death or frank injury in the CNS (Dietrich et al., 2005), although it has been shown to alter cell morphology in the NAc and certain other reward-related brain structures (Li et al., 2004; Robinson and Kolb, 2004). We propose that activation of $\mathrm{NF} \kappa \mathrm{B}$ during cocaine exposure may represent a prosurvival response to the insult of the drug. We hypothesize further that, in addition to promoting cell survival, $\mathrm{NF} \kappa \mathrm{B}$ activation causes structural changes in MSNs that mediate drug reward-based learning. Indeed, we show here that inhibition of $\mathrm{NF} \kappa \mathrm{B}$ not only decreases cocaine reward in naive mice but also blocks the ability of a prior course of cocaine exposure to increase an animal's sensitivity to the rewarding effects of subsequent doses of the drug. This important experiment was made possible by the unique features of HSV vectors, which express their transgenes for 3-5 d only. Thus, it was feasible to inhibit NF $\kappa$ B in the NAc, by HSV-IKKdn injection, during the cocaine pretreatment period only, and show that this manipulation prevented the ability of cocaine pretreatment to enhance subsequent CPP to the drug when transgene expression no longer occurs. However, overexpression of IKKca was not able to enhance cocaine CPP. Together, these results suggest that NF $\kappa \mathrm{B}$ activation by cocaine is necessary but not sufficient for normal rewarding responses to cocaine.

There is a growing literature that drug-induced activation of growth factor signaling, such as BDNF and GDNF, in the NAc mediates behavioral and cellular plasticity to cocaine or other drugs of abuse (Messer et al., 2000; Freeman and Pierce, 2002; Bolaños and Nestler, 2004; Graham et al., 2007; Russo et al., 2009). In addition, a few reports have shown in cell culture that $\mathrm{NF} \kappa \mathrm{B}$ activation is necessary for growth factor-induced neuronal outgrowth (Foehr et al., 2000; Gutierrez et al., 2005). We show here that NF $\kappa$ B activity is not only necessary for growth factor-induced PC12 cell differentiation but can also promote BDNF gene expression itself in the NAc. In the adult brain, BDNF has been found to promote synaptic plasticity through a TrkB and 75 receptor mechanism and to thereby regulate LTP- and LTD-related reorganization of the actin cytoskeleton (Woo et al., 2005; Rex et al., 2007; von Bohlen und Halbach et al., 2007). Interestingly, chronic cocaine administration has been shown to increase BDNF signaling to the NAc (Grimm et al., 2003; Graham et al., 2007) and to induce changes in actin within this brain region (Toda et al., 2006). Therefore, activation of neurotrophic factor signaling and $\mathrm{NF} \kappa \mathrm{B}$ may represent a fundamental pathway to promote both neuronal survival as well as the reorganization of actin and consequent changes in dendritic spine density observed in the NAc after chronic exposure to cocaine. 

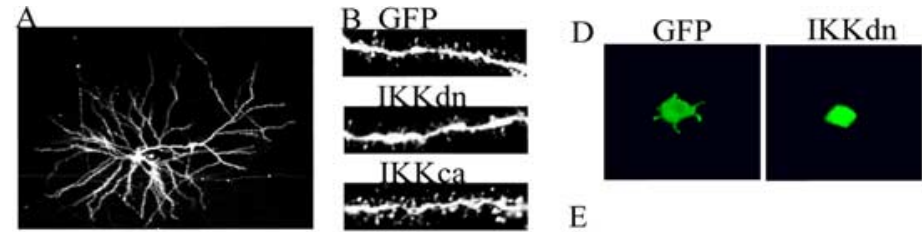

E
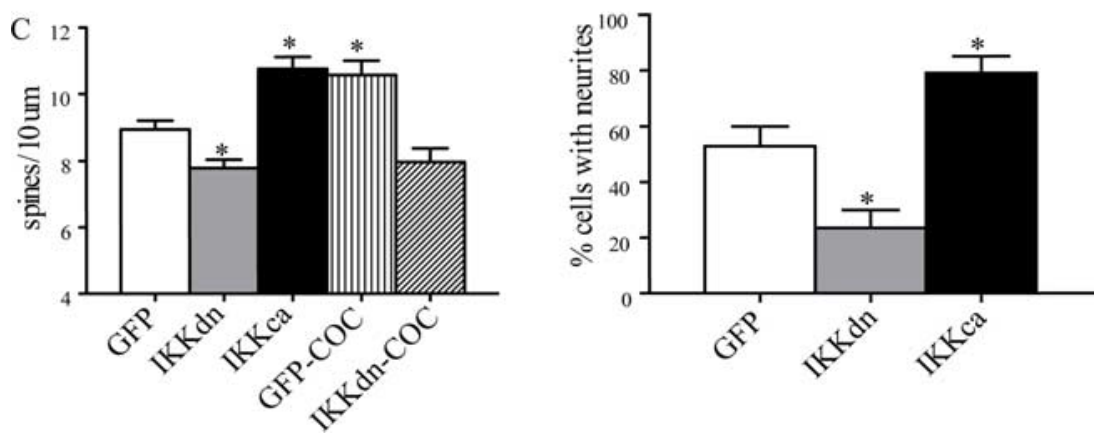

Figure 5. NF $\kappa B$ signaling is necessary for basal and cocaine-induced changes in the number of dendritic spines on NAc MSNs, as well as growth factor-induced neurite outgrowth in $\mathrm{PC} 12$ cells. $A-C$, Representative confocal scans from MSNs in the adult NAC; as shown in $C$, the total number of dendritic spines on MSNs (mean \pm SEM spines per $10 \mu \mathrm{m}$ ) is reduced by IKKdn and increased by IKKca ( ${ }^{*} p<0.05$, ANOVA, $n=4-8$ ). IKKdn also blocks the ability of chronic cocaine to increase dendritic spines. $D$ and $\boldsymbol{E}$ show that manipulation of $\mathrm{NF} \kappa \mathrm{B}$ signaling by IKK mutants similarly regulates the differentiation and outgrowth of $\mathrm{PC} 12$ cells by NGF $\left({ }^{*} p<0.05\right.$, ANOVA, $\left.n=8\right)$. Images in $\boldsymbol{D}$ show representative qualitative differences in neurite branching. Data in $\boldsymbol{E}$ are expressed as the mean number of cells with neurite outgrowth \pm SEM.
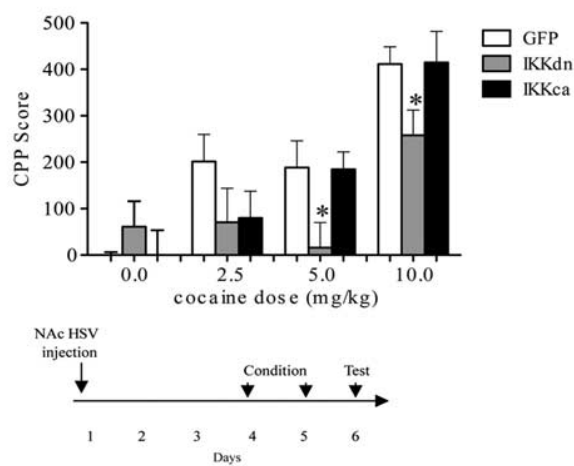

B
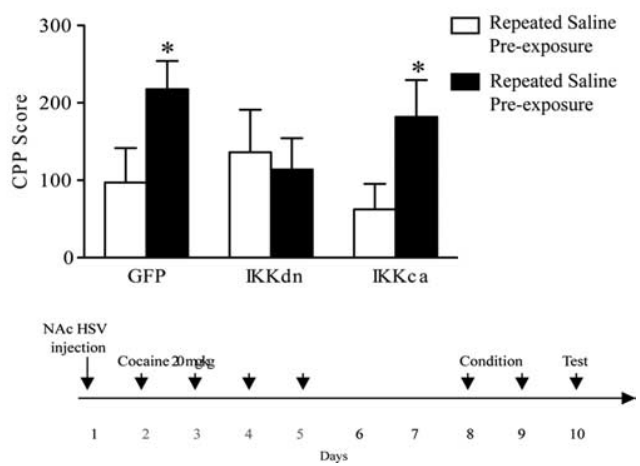

Figure 6. Regulation of cocaine CPP by NF $\kappa B$ signaling. $A$, Cocaine CPP (time in cocainepaired chamber minus time in saline-paired chamber) was measured after intra-NAc injections of HSV-GFP, -IKKdn, or -IKKca in male C57BL/6 mice. Animals infected with HSV-IKKdn had decreased preference for 5 and $10 \mathrm{mg} / \mathrm{kg}$ cocaine $\left({ }^{*} p<0.05\right.$, ANOVA, $\left.n=8-16\right)$. B, Enhanced levels of CPP after a prior course of cocaine exposure, as seen in the GFP and IKKca groups ( $p<$ 0.05 , Student's $t$ test, $n=8-16)$. In contrast, expression of IKKdn, during chronic cocaine pretreatment, prevents this enhancement of cocaine CPP. Below each graph, in $\boldsymbol{A}$ and $\boldsymbol{B}$, is the timeline for CPP and CPP sensitization paradigms. For baseline CPP, mice were injected with intra-NAc infusions of HSV-IKKCa, -IKKdn, or -GFP and conditioned for cocaine CPP starting $3 \mathrm{~d}$ after HSV infusion $(\boldsymbol{A})$. For CPP sensitization, mice were pretreated with cocaine $(20 \mathrm{mg} / \mathrm{kg}$, i.p. for $4 \mathrm{~d}$ ) at the onset of HSV expression, and after 3 additional days without treatment, animals received CPP training with $5 \mathrm{mg} / \mathrm{kg}$ cocaine $(\boldsymbol{B})$.

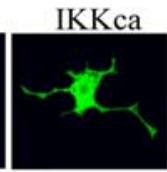

Although many previous studies have shown correlative evidence that increased numbers of dendritic spines on MSNs in the NAc are correlated with locomotor sensitization (Robinson and Kolb, 2004), there are both supportive and conflicting results from recent behavioral and molecular studies $(\mathrm{Di}-$ etz et al., 2009; Russo et al., 2009). For example, using a variety of approaches, our group has shown that chronic cocaine administration leads to the prolonged induction of the transcription factor $\triangle \mathrm{FosB}$ in the NAc, which underlies sensitized responses to cocaine and to other drugs of abuse and natural rewards (Nestler, 2008). Among the target genes for $\triangle \mathrm{FosB}$ in the $\mathrm{NAc}$ are several $\mathrm{NF} \kappa \mathrm{B}$ subunits (Ang et al., 2001), and we show in the present study that such induction of $\mathrm{NF} \kappa \mathrm{B}$ activity leads to an induction of dendritic spines on NAc MSNs and to sensitized drug responses. Consistent with this hypothesis is the observation that cocaine induction of dendritic spines occurs predominantly in $\mathrm{D}_{1}$ dopamine receptor expressing NAC MSNs that also show induction of $\triangle \mathrm{FosB}$ (Lee et al., 2006).

However, another target gene for $\triangle \mathrm{FosB}$ in the NAc is cyclindependent kinase 5 (Cdk5) (Bibb et al., 2001), and a known substrate for Cdk5 in this brain region is the transcription factor myocyte enhancing factor 2 (MEF2) (Pulipparacharuvil et al., 2008). Induction of Cdk5, and its subsequent phosphorylation and inhibition of MEF2, have been shown to also mediate the ability of chronic cocaine to induce dendritic spines on MSNs in this brain region (Norrholm et al., 2003; Pulipparacharuvil et al. 2008). Surprisingly, however, functional studies show that although inhibition of Cdk5, or activation of MEF2, prevents the cocaine-induced spine induction in the NAc, these manipulations paradoxically potentiate the behavioral responses to cocaine (Bibb et al., 2001; Taylor et al., 2007; Pulipparacharuvil et al., 2008).

The paradoxical differences between the effects of Cdk5MEF2 versus the effects of NF $\kappa \mathrm{B}$ on NAc spine density and cocaine's behavioral effects, despite the fact that induction of both pathways is mediated via $\Delta \mathrm{FosB}$, highlight the complexity of these intracellular pathways and the importance of future research. Our hypothesis is that the net effect of cocaine is to induce, via $\triangle$ FosB, NAc spine density through multiple downstream targets (e.g., NF $\kappa \mathrm{B}, \mathrm{Cdk} 5-\mathrm{MEF} 2$ ) and that the net consequence is sensitized behavioral responses to the drugs. At the same time, however, an individual target pathway like Cdk5MEF2 may in isolation elicit distinct behavioral effects via its own diverse downstream molecular consequences. Thus, it will be interesting to profile the downstream molecular pathways for the many cocaine and $\Delta \mathrm{FosB}$ targets to gain insight into the specific contributions of each pathway to cocaine-induced spinogenesis and heightened behavioral responses to cocaine. Additionally, by measuring the number of dendritic spines only, we are losing vital information about whether these new spines form functional synapses. It will therefore be important in future studies to consider the electrophysiological consequences of drug-induced spine plasticity.

In summary, the data presented here provide direct evidence that $\mathrm{NF} \kappa \mathrm{B}$ activation is a key regulator of the structural properties 
of MSNs in the NAc during chronic cocaine exposure and is necessary for sensitization to the rewarding effects of cocaine. These data also point to a novel mechanism for growth factorinduced neuroadaptations, providing fundamentally new insight into the molecular mechanisms controlling experiencedependent structural plasticity in the adult brain.

\section{References}

Ahmed SH, Koob GF (1998) Transition from moderate to excessive drug intake: change in hedonic set point. Science 282:298-300.

Ahmed SH, Lin D, Koob GF, Parsons LH (2003) Escalation of cocaine selfadministration does not depend on altered cocaine-induced nucleus accumbens dopamine levels. J Neurochem 86:102-113.

Ang E, Chen J, Zagouras P, Magna H, Holland J, Schaeffer E, Nestler EJ (2001) Induction of nuclear factor- $\kappa \mathrm{B}$ in nucleus accumbens by chronic cocaine administration. J Neurochem 79:221-224.

Asanuma M, Cadet JL (1998) Methamphetamine-induced increase in striatal NF- $\kappa$ B DNA-binding activity is attenuated in superoxide dismutase transgenic mice. Brain Res Mol Brain Res 60:305-309.

Barrot M, Olivier JD, Perrotti LI, DiLeone RJ, Berton O, Eisch AJ, Impey S, Storm DR, Neve RL, Yin JC, Zachariou V, Nestler EJ (2002) CREB activity in the nucleus accumbens shell controls gating of behavioral responses to emotional stimuli. Proc Natl Acad Sci USA 99:11435-11440.

Bhakar AL, Tannis LL, Zeindler C, Russo MP, Jobin C, Park DS, MacPherson S, Barker PA (2002) Constitutive nuclear factor- $\kappa$ B activity is required for central neuron survival. J Neurosci 22:8466-8475.

Bibb JA, Chen J, Taylor JR, Svenningsson P, Nishi A, Snyder GL, Yan Z, Sagawa ZK, Ouimet CC, Nairn AC, Nestler EJ, Greengard P (2001) Effects of chronic exposure to cocaine are regulated by the neuronal protein Cdk5. Nature 410:376-380.

Bolaños CA, Nestler EJ (2004) Neurotrophic mechanisms in drug addiction. Neuromolecular Med 5:69-83.

Boudreau AC, Wolf ME (2005) Behavioral sensitization to cocaine is associated with increased AMPA receptor surface expression in the nucleus accumbens. J Neurosci 25:9144-9151.

Chen LF, Greene WC (2004) Shaping the nuclear action of NF- $\kappa$ B. Nat Rev Mol Cell Biol 5:392-401.

Clark MS, Sexton TJ, McClain M, Root D, Kohen R, Neumaier JF (2002) Overexpression of 5-HT1B receptor in dorsal raphe nucleus using Herpes Simplex Virus gene transfer increases anxiety behavior after inescapable stress. J Neurosci 22:4550-4562.

Dietrich JB, Mangeol A, Revel MO, Burgun C, Aunis D, Zwiller J (2005) Acute or repeated cocaine administration generates reactive oxygen species and induces antioxidant enzyme activity in dopaminergic rat brain structures. Neuropharmacology 48:965-974.

Dietz DM, Dietz KC, Nestler EJ, Russo SJ (2009) Molecular mechanisms of psychostimulant-induced structural plasticity. Pharmacopsychiatry 42:S1-S10.

Ferrario CR, Gorny G, Crombag HS, Li Y, Kolb B, Robinson TE (2005) Neural and behavioral plasticity associated with the transition from controlled to escalated cocaine use. Biol Psychiatry 58:751-759.

Foehr ED, Lin X, O'Mahony A, Geleziunas R, Bradshaw RA, Greene WC (2000) NF- $\kappa \mathrm{B}$ signaling promotes both cell survival and neurite process formation in nerve growth factor-stimulated PC12 cells. J Neurosci 20:7556-7563.

Freeman AY, Pierce RC (2002) Neutralization of neutrophin-3 in the ventral tegmental area or nucleus accumbens differentially modulates cocaine-induced behavioral plasticity in rats. Synapse 46:57-65.

Graham DL, Edwards S, Bachtell RK, DiLeone RJ, Rios M, Self DW (2007) Dynamic BDNF activity in nucleus accumbens with cocaine use increases self-administration and relapse. Nat Neurosci 10:1029-1037.

Grimm JW, Lu L, Hayashi T, Hope BT, Su TP, Shaham Y (2003) Timedependent increases in brain-derived neurotrophic factor protein levels within the mesolimbic dopamine system after withdrawal from cocaine: implications for incubation of cocaine craving. J Neurosci 23:742-747.

Gutierrez H, Hale VA, Dolcet X, Davies A (2005) NF- $\kappa$ B signalling regulates the growth of neural processes in the developing PNS and CNS. Development 132:1713-1726

Hyman SE, Malenka RC, Nestler EJ (2006) Neural mechanisms of addic- tion: the role of reward-related learning and memory. Annu Rev Neurosci 29:565-598.

Jedynak JP, Uslaner JM, Esteban JA, Robinson TE (2007) Methamphetamine-induced structural plasticity in the dorsal striatum. Eur J Neurosci 25:847-853.

Kassed CA, Willing AE, Garbuzova-Davis S, Sanberg PR, Pennypacker KR (2002) Lack of NF- $\kappa$ B p50 exacerbates degeneration of hippocampal neurons after chemical exposure and impairs learning. Exp Neurol 176:277-288.

Krishnan V, Han MH, Graham DL, Berton O, Renthal W, Russo SJ, Laplant Q, Graham A, Lutter M, Lagace DC, Ghose S, Reister R, Tannous P, Green TA, Neve RL, Chakravarty S, Kumar A, Eisch AJ, Self DW, Lee FS, et al. (2007) Molecular adaptations underlying susceptibility and resistance to social defeat in brain reward regions. Cell 131:391-404.

Kumar A, Choi KH, Renthal W, Tsankova NM, Theobald DE, Truong HT, Russo SJ, Laplant Q, Sasaki TS, Whistler KN, Neve RL, Self DW, Nestler EJ (2005) Chromatin remodeling is a key mechanism underlying cocaineinduced plasticity in striatum. Neuron 48:303-314.

Kurdistani SK, Tavazoie S, Grunstein M (2004) Mapping global histone acetylation patterns to gene expression. Cell 117:721-733.

Lee KW, Kim Y, Kim AM, Helmin K, Nairn AC, Greengard P (2006) Cocaine-induced dendritic spine formation in D1 and D2 dopamine receptor-containing medium spiny neurons in nucleus accumbens. Proc Natl Acad Sci U S A 103:3399-3404.

Li Y, Acerbo MJ, Robinson TE (2004) The induction of behavioural sensitization is associated with cocaine-induced structural plasticity in the core (but not shell) of the nucleus accumbens. Eur J Neurosci 20:1647-1654.

Lin WW, Karin M (2007) A cytokine-mediated link between innate immunity, inflammation, and cancer. J Clin Invest 117:1175-1183.

Livak KJ, Schmittgen TD (2001) Analysis of relative gene expression data using real-time quantitative PCR and the $2^{-\Delta \Delta(\mathrm{T})}$ method. Methods 25:402-408.

Mattson MP (2005) NF- $\kappa$ B in the survival and plasticity of neurons. Neurochem Res 30:883-893.

Mattson MP, Meffert MK (2006) Roles for NF- $\kappa$ B in nerve cell survival, plasticity, and disease. Cell Death Differ 13:852-860.

Meffert MK, Baltimore D (2005) Physiological functions for brain NFkappaB. Trends Neurosci 28:37-43.

Meffert MK, Chang JM, Wiltgen BJ, Fanselow MS, Baltimore D (2003) $\mathrm{NF}-\kappa \mathrm{B}$ functions in synaptic signaling and behavior. Nat Neurosci 6:1072-1078

Mercurio F, Manning AM (1999) NF- $\kappa$ B as a primary regulator of the stress response. Oncogene 18:6163-6171.

Mercurio F, Zhu H, Murray BW, Shevchenko A, Bennett BL, Li J, Young DB, Barbosa M, Mann M, Manning A, Rao A (1997) IKK-1 and IKK-2: cytokine-activated $\mathrm{I} \kappa \mathrm{B}$ kinases essential for NF- $\kappa$ B activation. Science 278:860-866.

Messer CJ, Eisch AJ, Carlezon WA Jr, Whisler K, Shen L, Wolf DH, Westphal H, Collins F, Russell DS, Nestler EJ (2000) Role for GDNF in biochemical and behavioral adaptations to drugs of abuse. Neuron 26:247-257.

Nestler EJ (2008) Review. Transcriptional mechanisms of addiction: role of $\Delta$ FosB. Philos Trans R Soc Lond B Biol Sci 363:3245-3255.

Norrholm SD, Bibb JA, Nestler EJ, Ouimet CC, Taylor JR, Greengard P (2003) Cocaine-induced proliferation of dendritic spines in nucleus accumbens is dependent on the activity of cyclin-dependent kinase-5. Neuroscience 116:19-22.

O’Neill LA, Kaltschmidt C (1997) NF- $\kappa$ B: a crucial transcription factor for glial and neuronal cell function. Trends Neurosci 20:252-258.

Pulipparacharuvil S, Renthal W, Hale CF, Taniguchi M, Xiao G, Kumar A, Russo SJ, Sikder D, Dewey CM, Davis MM, Greengard P, Nairn AC, Nestler EJ, Cowan CW (2008) Cocaine regulates MEF2 to control synaptic and behavioral plasticity. Neuron 59:621-633.

Renthal W, Maze I, Krishnan V, Covington HE 3rd, Xiao G, Kumar A, Russo SJ, Graham A, Tsankova N, Kippin TE, Kerstetter KA, Neve RL, Haggarty SJ, McKinsey TA, Bassel-Duby R, Olson EN, Nestler EJ (2007) Histone deacetylase 5 epigenetically controls behavioral adaptations to chronic emotional stimuli. Neuron 56:517-529.

Rex CS, Lin CY, Kramár EA, Chen LY, Gall CM, Lynch G (2007) Brainderived neurotrophic factor promotes long-term potentiation-related cytoskeletal changes in adult hippocampus. J Neurosci 27:3017-3029.

Robinson TE, Kolb B (1997) Persistent structural modifications in nucleus 
accumbens and prefrontal cortex neurons produced by previous experience with amphetamine. J Neurosci 17:8491-8497.

Robinson TE, Kolb B (2004) Structural plasticity associated with exposure to drugs of abuse. Neuropharmacology 47 [Suppl 1]:33-46.

Russo SJ, Bolanos CA, Theobald DE, DeCarolis NA, Renthal W, Kumar A, Winstanley CA, Renthal NE, Wiley MD, Self DW, Russell DS, Neve RL, Eisch AJ, Nestler EJ (2007) IRS2-Akt pathway in midbrain dopamine neurons regulates behavioral and cellular responses to opiates. Nat Neurosci 10:93-99.

Russo SJ, Mazei-Robison MS, Ables JL, Nestler EJ (2009) Neurotrophic factors and structural plasticity in addiction. Neuropharmacology 56:73-82.

Shippenberg TS, Heidbreder C (1995) Sensitization to the conditioned rewarding effects of cocaine: pharmacological and temporal characteristics. J Pharmacol Exp Ther 273:808-815.

Taylor JR, Lynch WJ, Sanchez H, Olausson P, Nestler EJ, Bibb JA (2007) Inhibition of Cdk5 in the nucleus accumbens enhances the locomotoractivating and incentive-motivational effects of cocaine. Proc Natl Acad Sci U S A 104:4147-4152.

Thomas MJ, Malenka RC (2003) Synaptic plasticity in the mesolimbic dopamine system. Philos Trans R Soc Lond B Biol Sci 358:815-819.
Toda S, Shen HW, Peters J, Cagle S, Kalivas PW (2006) Cocaine increases actin cycling: effects in the reinstatement model of drug seeking. J Neurosci 26:1579-1587.

Ungless MA, Whistler JL, Malenka RC, Bonci A (2001) Single cocaine exposure in vivo induces long-term potentiation in dopamine neurons. Nature 411:583-587.

von Bohlen und Halbach O, Minichiello L, Unsicker K (2008) TrkB but not trkC receptors are necessary for postnatal maintenance of hippocampal spines. Neurobiol Aging 29:1247-1255.

Woo NH, Teng HK, Siao CJ, Chiaruttini C, Pang PT, Milner TA, Hempstead BL, Lu B (2005) Activation of p75NTR by proBDNF facilitates hippocampal long-term depression. Nat Neurosci 8:1069-1077.

Yao WD, Gainetdinov RR, Arbuckle MI, Sotnikova TD, Cyr M, Beaulieu JM, Torres GE, Grant SG, Caron MG (2004) Identification of PSD-95 as a regulator of dopamine-mediated synaptic and behavioral plasticity. Neuron 41:625-638.

Yu Z, Zhou D, Bruce-Keller AJ, Kindy MS, Mattson MP (1999) Lack of the p50 subunit of nuclear factor- $\kappa \mathrm{B}$ increases the vulnerability of hippocampal neurons to excitotoxic injury. J Neurosci 19:8856-8865. 